\title{
Strategies for the synthesis of brevipolides
}

\author{
Yudhi D. Kurniawan ${ }^{* 1}$ and A'liyatur Rosyidah ${ }^{2}$
}

\author{
Review \\ Address: \\ ${ }^{1}$ Research Center for Biomaterials, National Research and Innovation \\ Agency, Cibinong, 16911, Indonesia and ${ }^{2}$ Research Center for \\ Biology, National Research and Innovation Agency, Cibinong, 16911, \\ Indonesia \\ Email: \\ Yudhi D. Kurniawan* - yudhi.dwi.kurniawan@lipi.go.id \\ * Corresponding author \\ Keywords: \\ brevipolides; 5,6-dihydro- $\alpha$-pyrone; Furukawa-modified \\ Simmons-Smith cyclopropanation; Hyptis brevipes Poit; ring-closing \\ metathesis
}

\author{
Beilstein J. Org. Chem. 2021, 17, 2399-2416. \\ https://doi.org/10.3762/bjoc.17.157 \\ Received: 08 July 2021 \\ Accepted: 28 August 2021 \\ Published: 14 September 2021 \\ Associate Editor: B. Stoltz \\ (C) 2021 Kurniawan and Rosyidah; licensee Beilstein-Institut. \\ License and terms: see end of document.
}

\begin{abstract}
In recent years fifteen 5,6-dihydro- $\alpha$-pyrone derivatives, bearing either a distinctive cyclopropane or furan ring and named brevipolides A-O (1-15), have been isolated from the invasive plant Hyptis brevipes Poit. Their fascinating structural features, and the potent biological activities, including cytotoxicity against an array of human cancer cell lines and inhibition of the chemokine receptor CCR5, make them attractive synthetic targets. This review article highlights the recent synthetic methodologies and briefly summarizes their biological activities.
\end{abstract}

\section{Introduction}

Hyptis brevipes Poit. is an invasive plant species belonging to the mint family Lamiaceae [1-4]. This plant has been reported to originate from tropical America but is now distributed broadly in other tropical areas of the world [1-5]. This herbaceous weed plant is often encountered in wastelands, plantation crops, orchards, forest verges, and grows abundantly in the fallow ground $[1,3]$. Hence, it is a potential threat to the crops and natural vegetation [1]. The extract of this suffruticose plant has long been used in folk medicines to treat headaches (Panama) and diarrhea (Paraguay) [6], for protection after giving birth (Panama, Indonesia, Malaysia) [6-9], against worms for newborn infants (Indonesia) [6], for prevention and treatment of different types of cancer (Indonesia) [10] asthma and malaria (southern Sahara) [2,3], and to combat intestinal parasites (Bolivia) [5]. In addition, this plant has also been used as a natural pesticide, particularly in cereal conservations, and to repel mosquitoes (southern Sahara) $[2,3]$. Biological activity investigations of the plant extract revealed various results, including toxicity to brine shrimp [9], DNA intercalation as well as antibacterial and fungal $[4,9]$, and strong insecticidal activity against the 3rd instar larva of the cotton leaf worm Spodoptera littoralis (Biosd.) [7]. The essential oil extracted from the leaf of Hyptis brevipes Poit., furthermore, exhibited free radical scavenging and potential antitumor activities [2]. The ethnomedicinal background and preliminary biological studies triggered researchers to further examine the chemical con-stituents of the plant. 
In 2009, Kinghorn and co-workers reported the first study to determine bioactive chemicals in Hyptis brevipes Poit. and isolated six new 5,6-dihydro- $\alpha$-pyrone derivatives 1-6 along with other known compounds, including a 5,6-dihydro- $\alpha$-pyrone derivative 7 [11], from the whole plant collected in Tawangmangu village, Indonesia (Figure 1) [4]. These six new compounds, 1-6, were given the trivial names of brevipolides A-F, respectively, and the absolute configuration was determined by analysis of data obtained from their $C D$ spectra and by Mosher's ester formation, as C6R, C1'S, C2'S, and C4' $S$. The C6' stereocenter at that time could not be established due to a rapid epimerization during cinnamate hydrolysis. Later, in 2013 Pereda-Miranda and co-workers isolated ten compounds, namely brevipolides A-J (1-10), from the aerial part of Hyptis brevipes Poit. collected in Mexico [12]. The C6'S configuration was then determined by X-ray crystallographic data of the hydrogenated brevipolide derivative. It is interesting to note that all the brevipolides A-J (1-10) pose the conserved stereocenters and bear a cyclopropyl unit in the core structure, which are in agreement with the prior structural assignment of compounds 7-9, previously identified as unnamed inhibitors for the chemokine receptor 5 (CCR5), isolated from the Peruvian plant Lippia alva in 2004 [11]. Further, in 2017 Pereda-Miranda and co-workers isolated five more new 5,6-dihydro- $\alpha$-pyrone derivatives, namely brevipolides $\mathrm{K}-\mathrm{O}(\mathbf{1 1}-\mathbf{1 5})$, from the same plant [1]. The structures have been determined by a comprehensive combination of quantum mechanical calculations and experimental spectroscopic analysis of their NMR and ECD data, to have a unique tetrahydrofuran ring instead of the cyclopropane functionality. The absolute configuration of these five compounds were evaluated and all conserved as $\mathrm{C} 6 R, \mathrm{C} 1$ ' $S, \mathrm{C} 2{ }^{\prime} R$, C5'S, and C6'S.

Most brevipolide members exhibited cytotoxicity against various targets, including human colon, breast, laryngeal, cervix, prostate, and nasopharyngeal cancer cell lines with $\mathrm{ED}_{50}$ and $\mathrm{IC}_{50}$ values ranged in micromolar order $[1,4,12]$. One member showed activity in an enzyme-based ELISA NF- $\kappa B$ assay. Upon the mitochondrial transmembrane potential assay, three members demonstrated $\mathrm{ED}_{50}$ values in the nanomolar level [4]. Moreover, three of the members were identified as inhibitors of the chemokine receptor CCR5 [11]. Therefore, they are potential agents for treating human immunodeficiency virus (HIV).

The newly discovered brevipolides with interesting structural features in conjunction with promising biological activities have prompted the researchers to conduct synthetic studies. To date, there are six reported works in the literature for the syntheses of brevipolides, with the following details: two reports present the unsuccessful syntheses of brevipolide $H[13,14]$ and four reports cover the successful syntheses of brevipolide $H$ [15] and its enantiomer [16], brevipolide M [17], and brevipolide $\mathrm{N}$ $[17,18]$, respectively.

To the best of our knowledge, this work presents the first review on the synthetic strategies to obtain brevipolides $\mathrm{H}, \mathrm{M}$, and $\mathrm{N}$, aiming to achieve a deeper understanding of this area. It

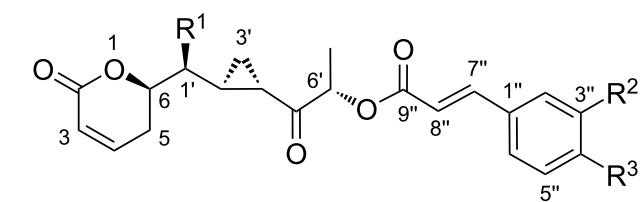

$\begin{array}{lrl}1 & \text { brevipolide } \mathrm{A}: \mathrm{R}^{1}=\mathrm{OAc} \\ 3 & \mathrm{C}: \mathrm{R}^{1}=\mathrm{OH} \\ 5 & \mathrm{E}: \mathrm{R}^{1}=\mathrm{OAC} \\ 7 & \mathrm{G}: \mathrm{R}^{1}=\mathrm{OH} \\ 8 & \mathrm{H}: \mathrm{R}^{1}=\mathrm{OH} \\ 10 & \mathrm{~J}: \mathrm{R}^{1}=\mathrm{OH}\end{array}$

$\mathrm{R}^{2}=\mathrm{H}$

$\mathrm{R}^{2}=\mathrm{OH}$

$\mathrm{R}^{2}=\mathrm{OH}$

$\mathrm{R}^{2}=\mathrm{H}$

$\mathrm{R}^{3}=\mathrm{OH}$

$\mathrm{R}^{2}=\mathrm{H}$

$\mathrm{R}^{3}=\mathrm{OH}$

$\mathrm{R}^{3}=\mathrm{OH}$

$\mathrm{R}^{2}=\mathrm{OH}$

$\mathrm{R}^{3}=\mathrm{OMe}$

$\mathrm{R}^{3}=\mathrm{OMe}$

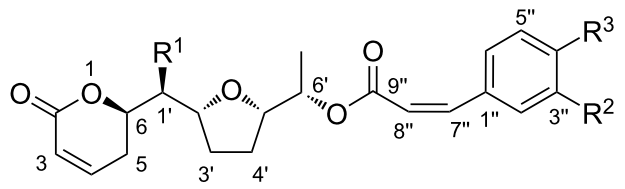

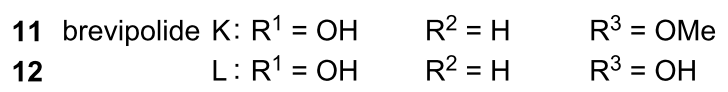<smiles>[R]c1ccc(/C=C/C(=O)O[C@H](C)C(=O)[C@@H]2C[C@H]2C([R7])[C@@H]2CC=CC(=O)O2)cc1[R]</smiles>
2 brevipolide $\mathrm{B}: \mathrm{R}^{1}=\mathrm{OAc}$
$\mathrm{R}^{2}=\mathrm{H}$
$\mathrm{R}^{3}=\mathrm{OH}$
$D: R^{1}=O H$
$\mathrm{R}^{2}=\mathrm{OH}$
$\mathrm{R}^{3}=\mathrm{OH}$
$\mathrm{F}: \mathrm{R}^{1}=\mathrm{OH}$
$\mathrm{R}^{2}=\mathrm{H}$
$\mathrm{R}^{3}=\mathrm{OH}$
$\mathrm{I}: \mathrm{R}^{1}=\mathrm{OH}$
$\mathrm{R}^{2}=\mathrm{H}$
$\mathrm{R}^{3}=\mathrm{OMe}$

4

9<smiles>[R]c1ccc(/C=C/C(=O)O[C@H](C)[C@H]2CC[C@H](C([R1])[C@H]3CC=CC(=O)O3)O2)cc1[R]</smiles>

13 14
brevipolide $M: \mathrm{R}^{1}=\mathrm{OH}$
$\mathrm{N}: \mathrm{R}^{1}=\mathrm{OH}$
$\mathrm{O}: \mathrm{R}^{1}=\mathrm{OH}$

15
$\mathrm{R}^{3}=\mathrm{OMe}$

$\mathrm{R}^{2}=\mathrm{H} \quad \mathrm{R}^{3}=\mathrm{OH}$

$\mathrm{R}^{2}=\mathrm{OH} \quad \mathrm{R}^{3}=\mathrm{OH}$

Figure 1: Structures of brevipolides A-O (1 - 15) 
also provides a summary of the biological activities of brevipolides. This present review is chronologically organized, encompassing all synthetic works published since 2014 .

\section{Review}

\section{Syntheses}

\section{Kumaraswamy's approach to brevipolide $\mathrm{H}(\mathbf{8})$}

In 2014, Kumaraswamy and co-workers initiated the first attempt to synthesize brevipolide $\mathrm{H}$ (8, Scheme 1) [14]. In the retrosynthesis, the target compound $\mathbf{8}$ is achieved via esterification of the $\beta$-hydroxycyclopropyl intermediate $\mathbf{1 6}$ with the commercially available $(E)$-p-methoxycinnamic acid (17). The vital intermediate $\mathbf{1 6}$ is expected from cyclopropyl epoxy alcohol $\mathbf{1 8}$ which in turn can be prepared from allylic alcohol 19 via the Furukawa-modified Simmons-Smith cyclopropanation and VO-mediated epoxidation. Acetylfuran (20) is chosen as the six-carbon precursor for the synthesis.

The forward synthesis transformed 2-acetylfuran (20) to its corresponding alcohol $\mathbf{2 1}$ through an asymmetric transfer hydrogenation catalyzed by a ruthenium complex $(0.5 \mathrm{~mol} \%)$ in $98 \%$ yield with $95 \%$ ee (Scheme 2). The azeotropic mixture of $\mathrm{HCO}_{2} \mathrm{H} / \mathrm{Et}_{3} \mathrm{~N}$ 5:2 was employed as the hydrogen source. Following protection of the alcohol moiety with $\mathrm{PMBCl}$, ether 22 was realized in $93 \%$ yield. Afterwards, this species was transformed into the $\gamma$-keto $\alpha, \beta$-unsaturated aldehyde $\mathbf{2 3}$ through an NBS-assisted furan oxidation procedure in moderate yield $(65 \%)$. The keto functionality was reduced in a stereoselective manner adopting Luche conditions to provide diol $\mathbf{2 4}$ (dr 97:3), which after masking the primary alcohol moiety as a silyl ether, allowed isolation of the desired product 25 in $86 \%$ yield. This intermediate possessed the correct chirality on the free secondary alcohol to influence the stereo-outcome for the later cyclopropanation step. Thus, treatment of $\mathbf{2 5}$ with diethyl- zinc and diiodomethane delivered the expected syn-cyclopropyl carbinol 26 as the major diastereomer (dr 95:5) in 90\% yield. After the protection of the secondary alcohol as MOM ether, the primary alcohol was liberated using TBAF to give compound 27 in $97 \%$ yield over two steps. The alcohol group in $\mathbf{2 7}$ was then oxidized to the corresponding aldehyde under Swern conditions and subsequently subjected to a Wittig reaction with a two-carbon phosphonium ylide reagent. The desired $\alpha, \beta-$ unsaturated ester $\mathbf{2 8}$ was then isolated in $80 \%$ yield over two steps. Reduction of the ester provided allylic alcohol 29 (92\%) ready for later epoxidation. After considerable optimizations, the authors found that the dropwise addition of TBHP to $\mathbf{2 9}$ in refluxing benzene solution containing a catalytic amount of $\mathrm{VO}(\mathrm{acac})_{2}$ afforded the desired epoxide $\mathbf{3 0}$ after one hour in $85 \%$ yield (dr 10:1). This species was next converted to the terminal carbonate derivative $\mathbf{3 1}$ to transform the epoxy functionality to a vicinal diol through a two-step manipulation involving protection of the terminal alcohol as Boc derivative followed by $\mathrm{BF}_{3} \cdot \mathrm{Et}_{2} \mathrm{O}$-promoted intramolecular oxacyclization. After TBS protection, intermediate 32 was collected in $86 \%$ yield from epoxide 30. Basic methanolysis of the cyclic carbonate followed by treatment with $\mathrm{NaH}$ and $\mathrm{N}$-tosylimidazole then afforded terminal epoxide 34 in $97 \%$ yield. Unfortunately, attempts to open the epoxide using vinyl Grignard reagent followed by esterification with acrylic acid (35) proved to be inefficient due to low reproducibility and poor isolation of product 36.

The strategy was altered by changing the terminal epoxide $\mathbf{3 4}$ to an allylic alcohol (95\%) utilizing dimethyl sulfonium methylide followed by esterification with 3-butenoic acid (37) under Steglich conditions (Scheme 3). The resulting product $\mathbf{3 8}$ was isolated in $86 \%$ yield. A subsequent ring-closing metathesis reaction and DBU-assisted double bond migration then

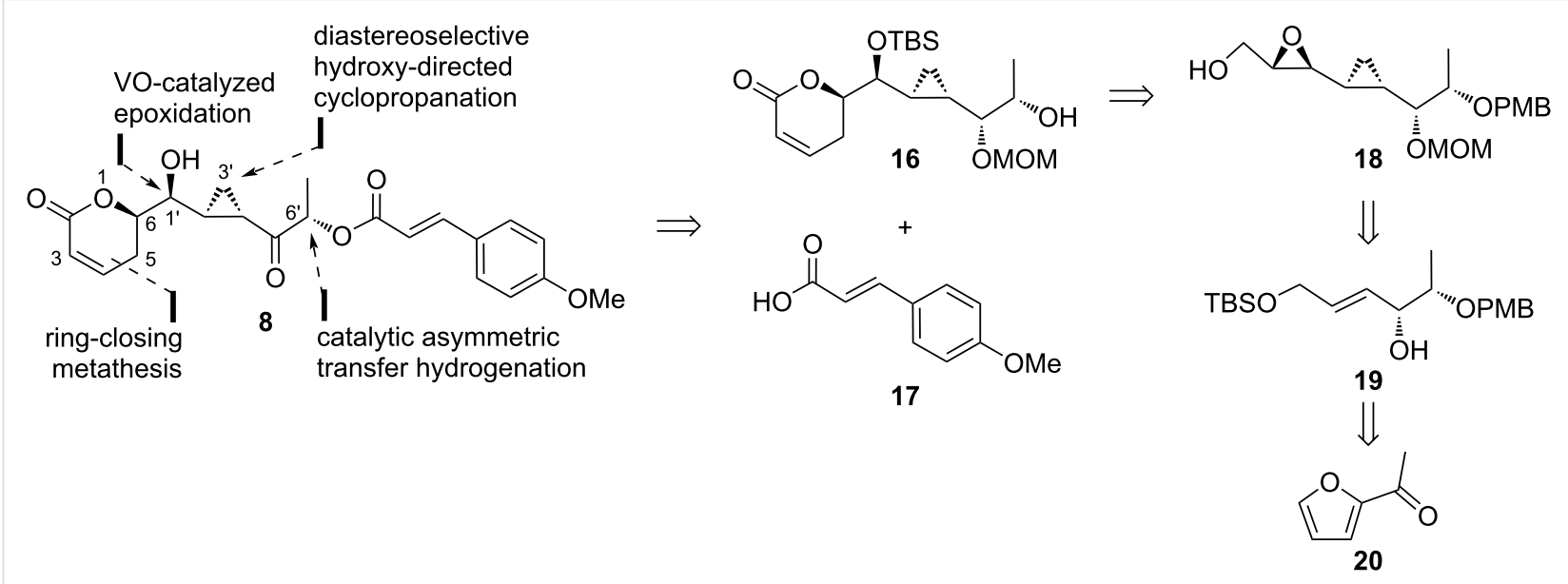




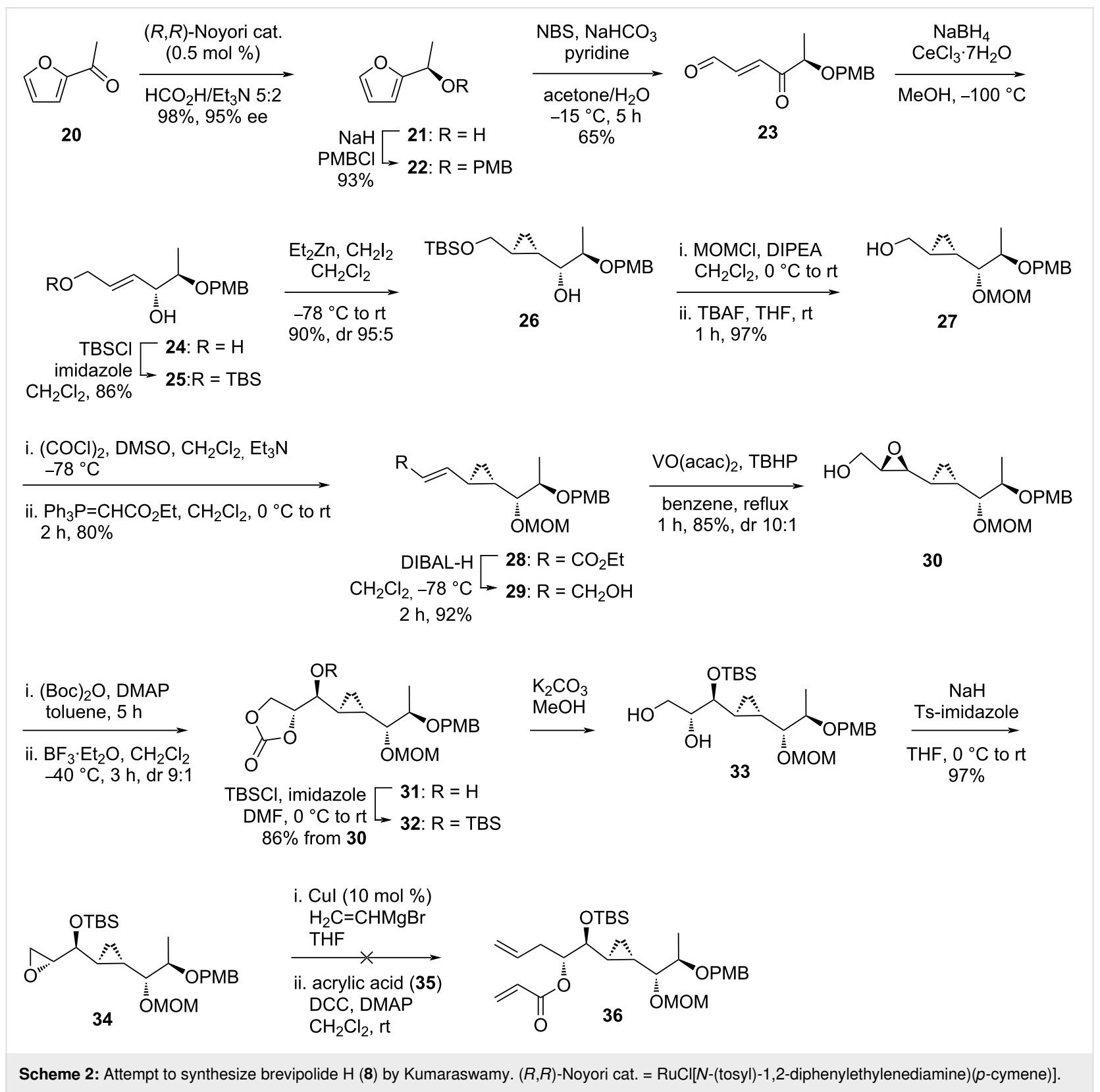

furnished the anticipated structure 39. The PMB functionality was removed using DDQ to form alcohol 40. At this point, the stereogenic center at the C6' carbon required an inversion to match the target molecule. Thus, a standard Mitsunobu procedure followed by basic methanolysis were conducted. The desired inverted product 16, however, did not form. The authors hypothesized a prospective possibility to obtain ent-21 from precursor $\mathbf{2 0}$ by utilizing an antipode ligand in a Noyori reduction. As the continuation, intermediate $\mathbf{4 0}$ was coupled with (E)-p-methoxycinnamic acid (17) under Steglich conditions and treated with a Lewis acid to remove the MOM protection giving ester 41. Oxidation of the secondary alcohol of this intermediate to its keto derivative was problematic and gave no desired product 42 after considerable experimentations. Eventually, the isolation of $\mathbf{4 3}$ marked the end of the synthetic study after treatment of $\mathbf{4 1}$ with HF.pyridine, which is the reduced form of 6'-epi-brevipolide H. Kumaraswamy and co-workers also performed a bioassay study for compounds $\mathbf{4 1}$ and $\mathbf{4 3}$ and found a higher cytotoxicity for the latter derivative against the MFC-7 cancer cell line.

\section{Hou's strategy to ent-brevipolide $\mathrm{H}$ (ent-8)}

Hou and co-workers, in 2014, demonstrated an efficient approach to synthesize brevipolide $\mathrm{H}(\mathbf{8})$, but unexpectedly ended up with the isolation of its enantiomer (ent-8) [16]. Common to the most of the reported retrosynthetic analyses of brevipolide, 


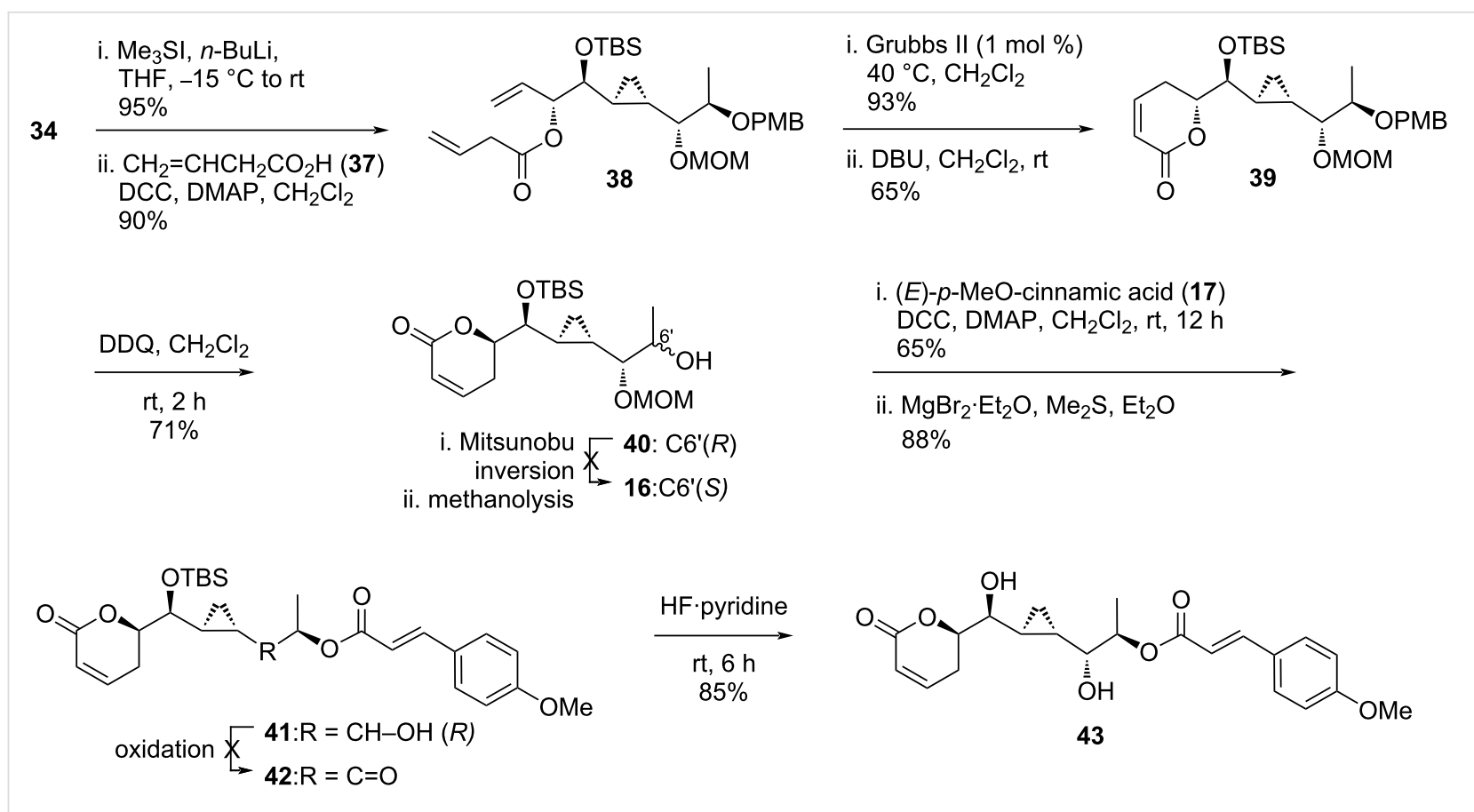

Scheme 3: Attempt to synthesize brevipolide H (8) by Kumaraswamy (continued)

compound $\mathbf{8}$ is disconnected at the cinnamate ester bond giving $\beta$-hydroxy cyclopropyl intermediate $\mathbf{4 4}$ and $(E)$ - $p$-methoxycinnamic acid (17) (Scheme 4). The $\beta$-hydroxy moiety in $\mathbf{4 4}$ can be installed via Sharpless dihydroxylation of the silyl enol ether derived from ketone $\mathbf{4 5}$. The 5,6-dihydro- $\alpha$-pyrone group in ketone $\mathbf{4 5}$ is envisaged from protected diol $\mathbf{4 6}$ by the sequence of Mitsunobu esterification, ring-closing metathesis, and basepromoted double bond migration. The cyclopropyl functionality in $\mathbf{4 6}$ can be assembled from the reaction of sulfur ylide and the $\alpha, \beta$-unsaturated ketone 47 , which in turn can be realized from the cross metathesis between commercially available ethyl vinyl ketone (48) and the $C_{2}$-symmetrical diene-diol 49.

The synthesis commenced with the monoprotection of the known diene-diol ent-49 as TBS ether affording compound $\mathbf{5 0}$ in $76 \%$ yield, which served as an excellent strategy to direct the later cross metathesis reaction to one site of the olefin over another (Scheme 5). Thus, the desired $\alpha, \beta$-unsaturated ester $\mathbf{5 1}$ was afforded in $78 \%$ yield as an $(E)$-isomer exclusively after reaction with excess ethyl vinyl ketone (48) in the presence of a catalytic amount of Grubbs II catalyst and CuI. The free secondary alcohol in $\mathbf{5 1}$ required a protection prior to the next transformation. For this purpose, $\mathrm{MEMCl}$ was chosen instead of the previously arranged $\mathrm{MOMCl}$, as the MEM functionality was found to have a better impact on the stereoselectivity of the later cyclopropanation reaction. Thus, the MEM ether $\mathbf{5 2}$ was obtained in $95 \%$ yield and subjected to in situ prepared dimethyl sulfoxonium methylide at low temperature to affect the Michael-initiated ring closure cyclopropanation at the more electrophilic olefin. The $\alpha$-keto cyclopropyl intermediate $\mathbf{5 3}$ was formed in $79 \%$ yield with a dr value of $>20: 1$. Reducing the proportion of DMF to $5 \%$ with respect to THF in the reaction mixture was hypothesized as the key factor for maximizing the anti-addition of the sulfoxonium ylide to $\mathbf{5 2}$. Hou highlighted that the good diastereoselectivity control for the sulfoxonium ylide addition to acyclic $\alpha, \beta$-unsaturated substrates such as $\mathbf{5 2}$ observed in their work represented the first example in literature. Hereupon, deprotonation of $\mathbf{5 3}$ over LiHMDS followed by addition of TBSOTf at low temperature successfully formed the (Z)-silyl enol ether 54. Application of the Sharpless asymmetric dihydroxylation, promoted by AD-mix- $\beta$, gave the expected $\beta$ - $(R)$-hydroxy cyclopropyl product 55 in $84 \%$ yield with moderate diastereoselectivity $(\mathrm{dr}=2)$. The formation of ester $\mathbf{5 6}$ was achieved through reaction of $\mathbf{5 5}$ with the pre-activated acid $\mathbf{1 7}$ with $N, N$ '-diisopropylcarbodiimide (DIC) and DMAP. Removal of the TBS protection with a fluoride source and succeeding Mitsunobu inversion with 3-butenoic acid (37) went smoothly to give ester 57. This intermediate accommodated all the centers of the stereochemical brevipolides but in the mirror image of the natural configuration. After sequential ring-closing metathesis, base-promoted olefin migration, and MEM removal, the ent-brevipolide $\mathrm{H}$ (ent-8) was obtained. This compound showed inhibition activity in the preliminary assay against the cell proliferation of the human hormone-refractory prostate cancer cell line (PC-3). 

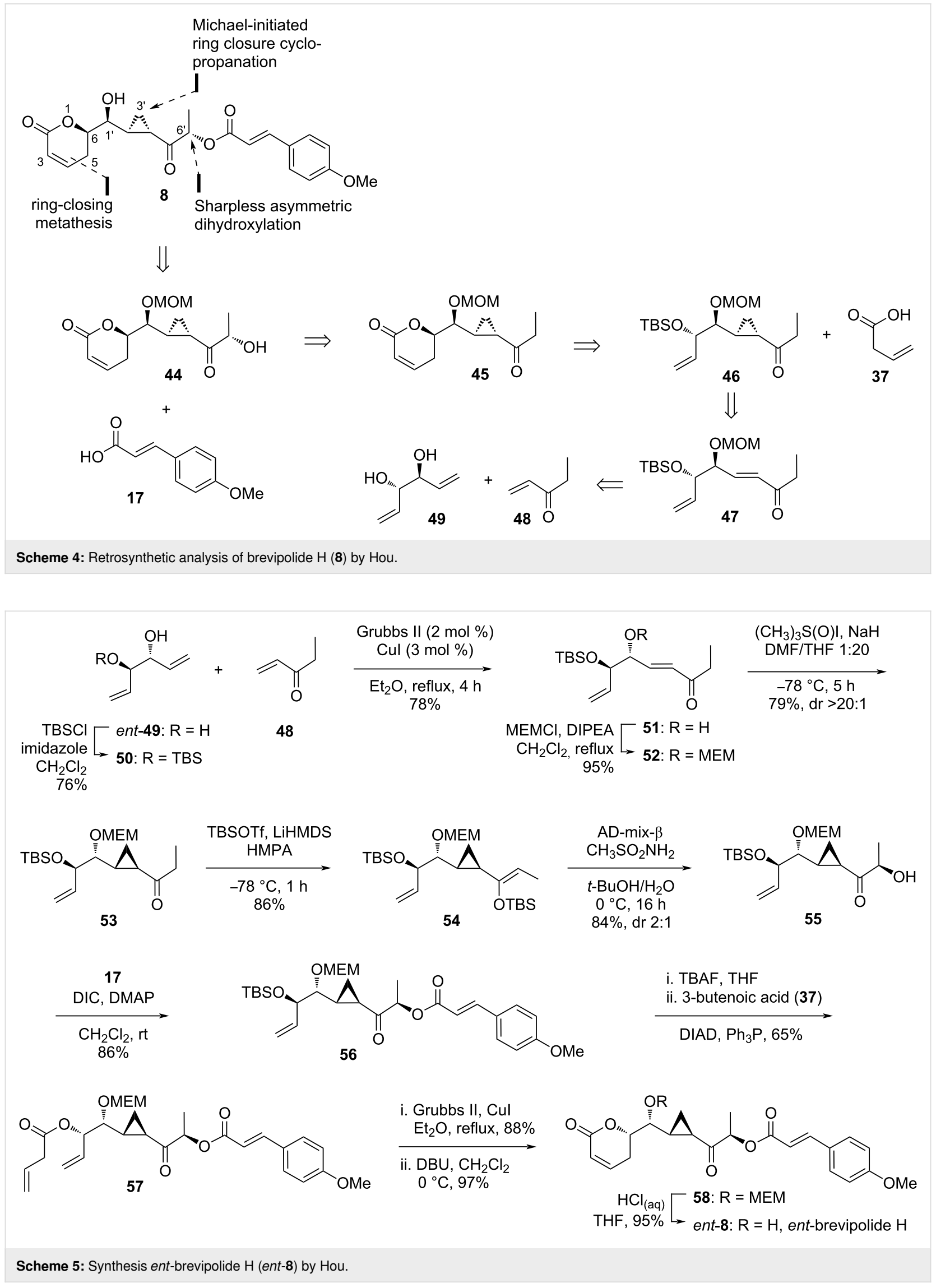


\section{Mohapatra's strategy to brevipolide $\mathrm{H}(\mathbf{8})$}

As part of the interest in synthesizing biologically active cyclopropane-containing natural products, Mohapatra and co-workers in 2015 started their attempt to prepare brevipolide $\mathrm{H} \mathrm{(8)} \mathrm{[13]}$ The retrosynthesis started with envisaging a common 12-carbon intermediate $\mathbf{5 9}$ which can be derived from unsaturated ketone 60 (Scheme 6). The cyclopropyl moiety in 60 can be realized from allylic alcohol $\mathbf{6 1}$ via the Furukawa's modified Simmons-Smith cyclopropanation protocol. Eventually, transcrotonaldehyde (62) is selected as the precursor for this study.

The study began with the enantioselective epoxidation of transcrotonaldehyde (62) under Jørgensen conditions using organocatalyst $\mathbf{6 3}$, followed by a two-carbon homologation to obtain $\alpha, \beta$-unsaturated epoxy ester $\mathbf{6 4}$ in 78\% yield over two steps ( $\mathrm{dr}$ 95:5, de 93:7) (Scheme 7). Then, the epoxide ring was opened regioselectively by $p$-methoxybenzyl alcohol utilizing a palla$\operatorname{dium}(0)$ catalyst to afford the secondary allylic alcohol $\mathbf{6 5}$ in $96 \%$ yield. The free alcohol group was protected as tertbutylsilyl (TBS) ether $\mathbf{6 6}(95 \%)$ and the ester group was reduced to the primary alcohol $67(95 \%)$. After protection as tert-butyldiphenylsilyl (TBDPS) ether 68 (98\%), a Simmons-Smith cyclopropanation was attempted yet no desired product was obtained. Hence, the PMB-protecting group was first removed and the cyclopropyl product $\mathbf{6 9}$ was successfully attained in $97 \%$ yield with very high diastereoselectivity ( $d r$ 99:1). The free secondary alcohol group was re-protected as
MOM ether 70 in $96 \%$ yield. After removal of the TBDPS group, the resulting free primary alcohol was oxidized under Dess-Martin conditions followed by Grignard reaction with vinylmagnesium bromide. The allylic alcohol products $\mathbf{7 1}$ and 72 were obtained as a diastereomeric mixture in $86 \%$ yield with poor stereoselectivity.

To gain more of the desired diastereomer $\mathbf{7 1}$, the mixture of $\mathbf{7 1}$ and $\mathbf{7 2}$ was subjected to a two-step procedure involving a Dess-Martin oxidation followed by stereoselective reduction (Scheme 8). Among a selection of reagents, Mohapatra found that lithium tri-tert-butoxyaluminum hydride in ethanol at low temperature furnished $\mathbf{7 1}$ as a single diastereoisomer in $94 \%$ yield. The allylic alcohol moiety was protected as TBDPS ether $73(92 \%)$ and oxidatively cleaved following Jin's one step dihydroxylation-oxidation protocol using a $\mathrm{NaIO}_{4} /$ (cat.) $\mathrm{OsO}_{4}$ system. Allylation of the resulting aldehyde $\mathbf{7 4}$ was best performed under Brown's protocol at low temperature utilizing a chiral allyl reagent prepared from allylmagnesium bromide and (+)- $B$-chloro-diisopinocampheylborane. By this route, the alcohol product 75 was isolated in $81 \%$ yield (dr 85:15). Esterification of this molecule with acryloyl chloride (76) went smoothly providing the diene $77(85 \%)$, which, after the sequential ring-closing metathesis with Grubbs I catalyst and TBS removal, gave the 5,6-dihydro- $\alpha$-pyrone $\mathbf{7 8}$ in $71 \%$ yield over two steps. The stereocenter at the C6' carbon demanded an inversion to fit the natural form. The standard Mitsunobu inver-

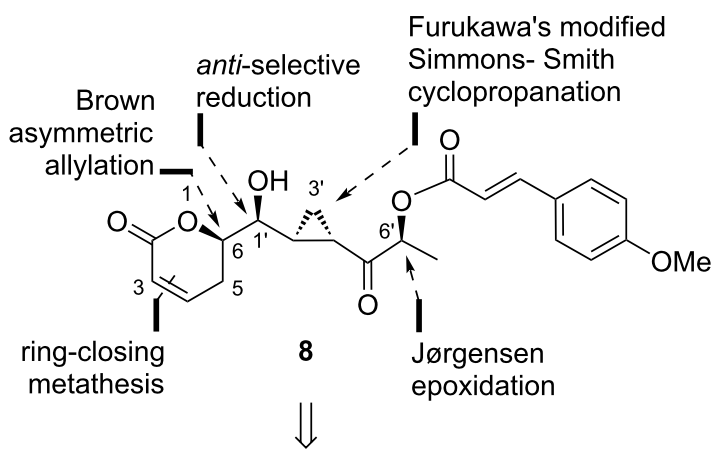

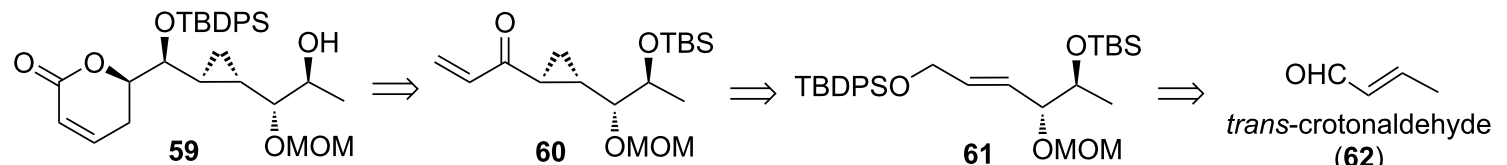<smiles>COc1ccc(/C=C/C(=O)O)cc1</smiles> 


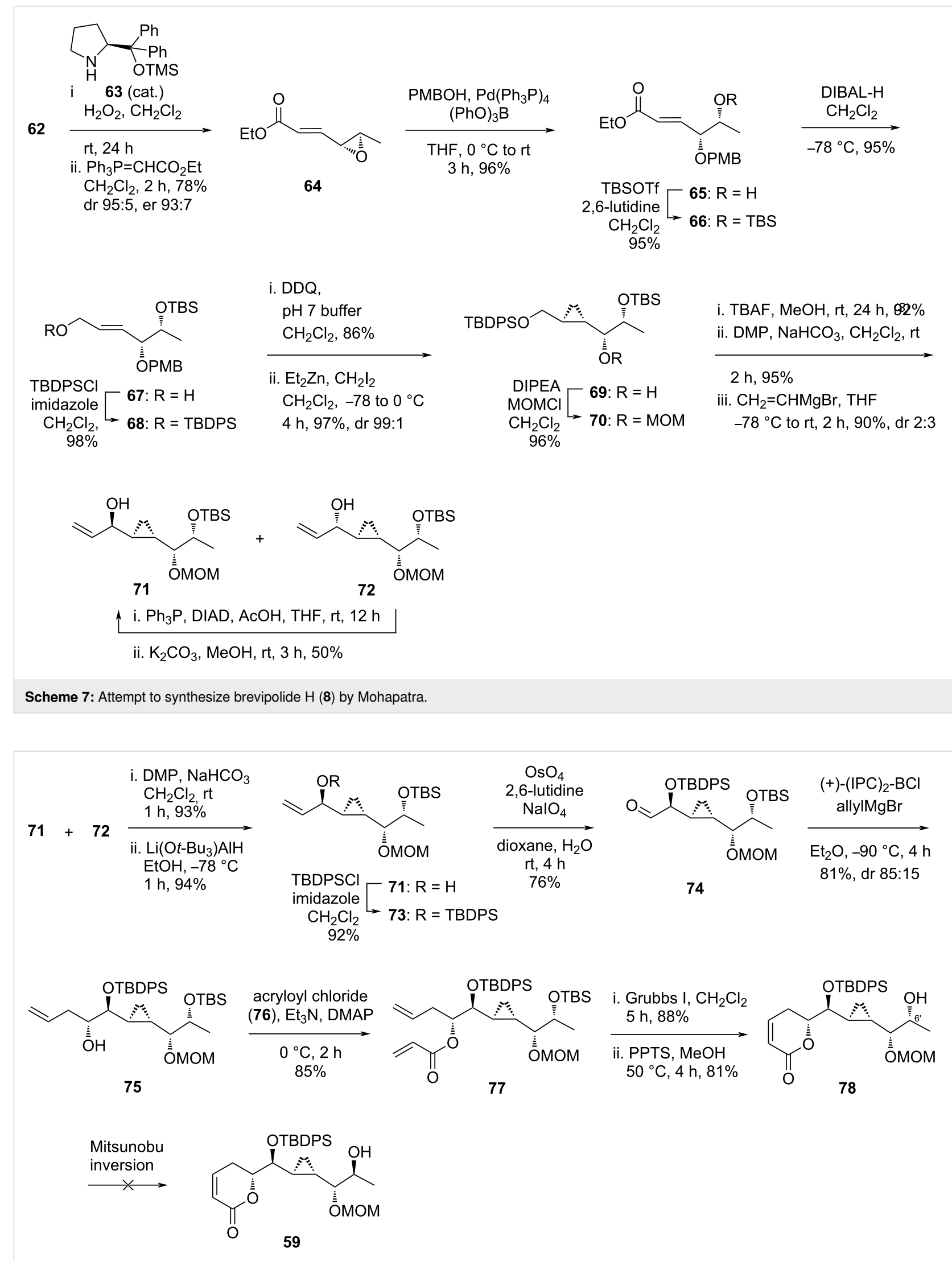

Scheme 8: Attempt to synthesize brevipolide H (8) by Mohapatra (continued). (+)-(IPC) $)_{2}-\mathrm{BCl}=(+)-B$-chloro-diisopinocampheylborane. 
sion protocol, unfortunately, failed to reach the expected transformation. The isolation of $\mathbf{7 8}$ ended their attempt to synthesize brevipolide $\mathrm{H}$.

\section{Hou's strategy to brevipolide $\mathrm{H}$ (8)}

Two years after the successful synthesis of ent-brevipolide $\mathrm{H}$ (ent-8), in 2016, Hou and co-workers reported the first total synthesis of natural brevipolide $\mathrm{H} \mathrm{(8)} \mathrm{[15].} \mathrm{The} \mathrm{retrosynthesis}$ was initiated by disconnection of the cinnamate ester bond to give intermediate 79. The 5,6-dihydro- $\alpha$-pyrone moiety is obtained via ring-closing metathesis reaction of acrylate ester $\mathbf{8 0}$, which in turn can be proposed from allylic alcohol $\mathbf{8 1}$ via Furukawa's modified Simmons-Smith cyclopropanation (Scheme 9). The species $\mathbf{8 1}$ can be constructed through the sequential epoxide opening and esterification of compound $\mathbf{8 2}$ This molecule is expected to be available from cross metathesis of olefins $\mathbf{8 3}$ and $\mathbf{8 4}$. These two intermediates can then be readily prepared from optically active oxirane $\mathbf{8 5}$ and its enantiomer which can be derived through the Sharpless epoxidation of penta-1,4-dien-3-ol (86).

In the synthesis, desymmetrization of $\mathbf{8 6}$ was achieved under Sharpless epoxidation conditions employing a $t$-BuOOH/(+)-DIPT/Ti(O-iPr $)_{4}$ system to give epoxide $\mathbf{8 5}$ $(63 \%)$, which was subsequently protected as PMB ether 84 in $86 \%$ yield (Scheme 10). In parallel, the same precursor 86 was subjected to another Sharpless epoxidation using (-)-DIPT affording ent-85 in $65 \%$ yield. A series of functional group transformations involving hydroxy group protection, reduction of the epoxide, protection of the resultant free alcohol as TBS ether, and removal of the acetal protection afforded the expected allylic alcohol 83. Accordingly, cross-metathesis reaction between 83 and 84 was successfully achieved utilizing Grubbs II catalyst to give the adduct $\mathbf{8 2}$ in $76 \%$ yield. The $E / Z$ ratio for this compound was determined from the ${ }^{1} \mathrm{H}$ NMR spectral analysis as $>20: 1$. After protection of the secondary alcohol as MEM ether $\mathbf{8 8}$ (83\%), the epoxide ring was opened with vinylmagnesium bromide to give the allylic alcohol $\mathbf{8 9}$ (92\%). The acrylate ester 90 was smoothly obtained from this molecule in $95 \%$ yield and deprotected using TMSBr to give the allylic alcohol 81. Subjection of this compound to a system containing $\mathrm{Et}_{2} \mathrm{Zn} / \mathrm{CH}_{2} \mathrm{I}_{2}$ successfully furnished the expected syn adduct in $65 \%$ yield as a single diastereomer. Oxidation of this molecule under Swern conditions proceeded smoothly giving ketone 91 in 94\% yield, which was highlighted as an important observation as the same transformation using the similar compound was reported to be unsuccessful [14]. Ring-closing metathesis of this compound installed the 5,6-dihydro- $\alpha$-pyrone moiety, and TBS removal followed by esterification with 4-methoxycinnamic acid provided compound 92. After removal of the PMB group using DDQ, the natural brevipolide $\mathrm{H}(\mathbf{8})$ was successfully achieved.

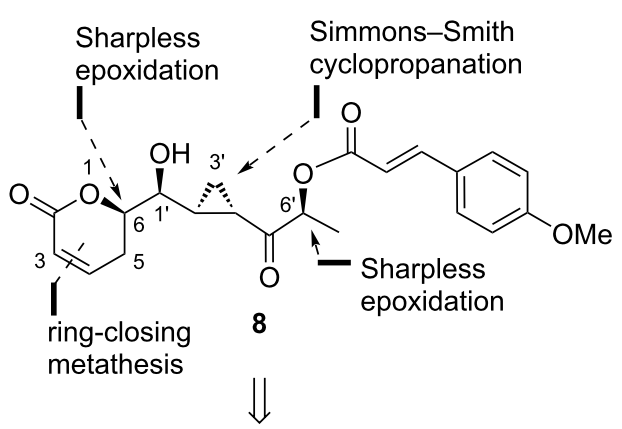

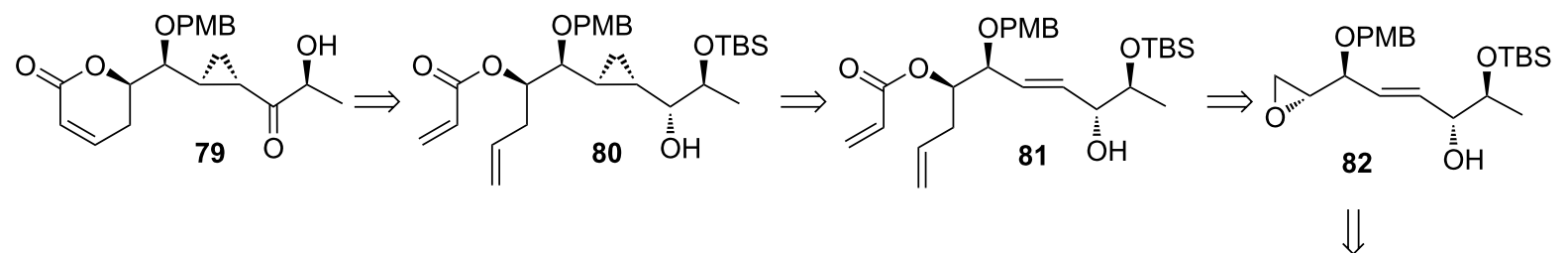

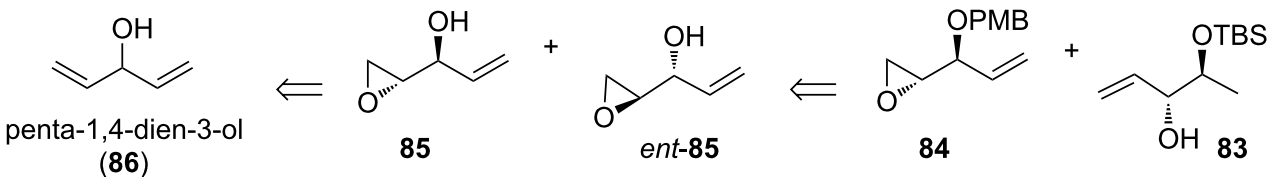




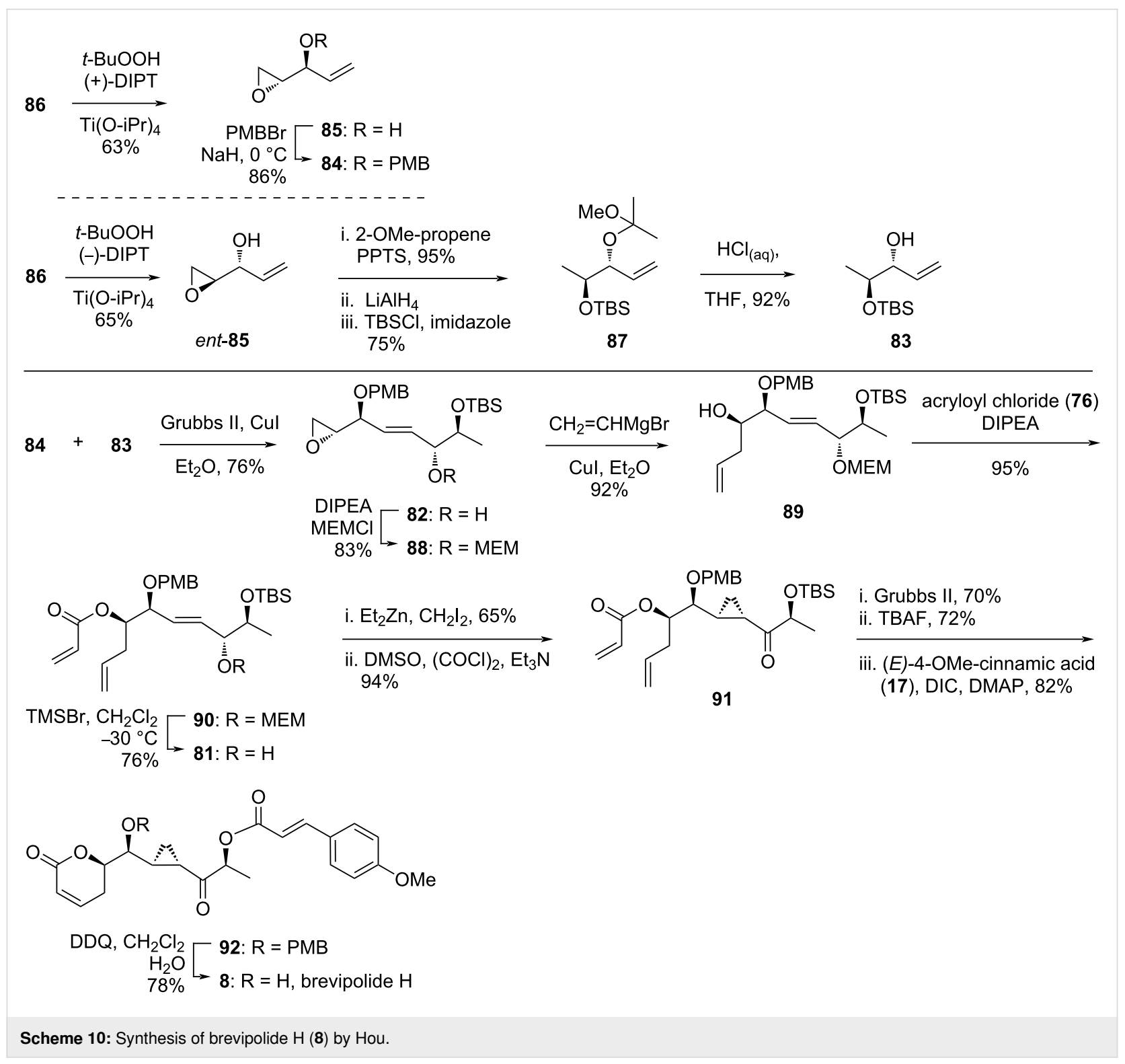

\section{Sabitha's strategy to brevipolide M (13)}

Sabitha and Raju demonstrated the first total synthesis of brevipolide M (13) in 2017 [17]. In the retrosynthesis, compound 93 is hypothesized from the Mitsunobu inversion at the C6' stereocenter with (E)-p-methoxycinnamic acid (17) and ring-closing metathesis of tetrahydrofuran $\mathbf{9 3}$ (Scheme 11). The olefin moieties can be installed via stereoselective allylation and cinnamic acid esterification of $\mathbf{9 4}$, which is derived from symmetrical alcohol 95. The right-hand side portion of this molecule can be constructed by epoxidation of the allylic alcohol derived from $\alpha, \beta$-unsaturated ester 96 and the cyclization to form the furan ring is then expected to occur concurrently. (-)-Diethyl tartrate (98) was eventually selected as the precursor to construct the unsaturated ester 96 after a double two-carbon homologation.
In the reverse order, the synthesis of $\mathbf{1 3}$ began with the conversion of diethyl tartrate 98 into the PMB-protected $\alpha, \beta$-unsaturated ester $\mathbf{9 7}$ in four steps adopting the literature procedure (Scheme 12). The chemoselective reduction of the olefin in $\mathbf{9 7}$ was furnished in $88 \%$ yield applying $\mathrm{NiCl}_{4} \cdot 6 \mathrm{H}_{2} \mathrm{O} / \mathrm{NaBH}_{4}$ as reagents in methanol followed by reduction of the ester part with DIBAL-H providing the primary alcohol 99 (90\%). Oxidation of this moiety with IBX to its corresponding aldehyde served as a substrate for the two-carbon homologation via Wittig reaction giving ester 96 in $80 \%$ yield over the two steps. After reduction of the ester group to its primary alcohol counterpart, the Sharpless epoxidation protocol was applied to the double bond using (-)-DET to afford chiral oxirane 100 in $85 \%$ yield. The free primary alcohol was then protected as tosyl ester 101 and treated with $p$-TSA to induce intramolecular cycliza- 


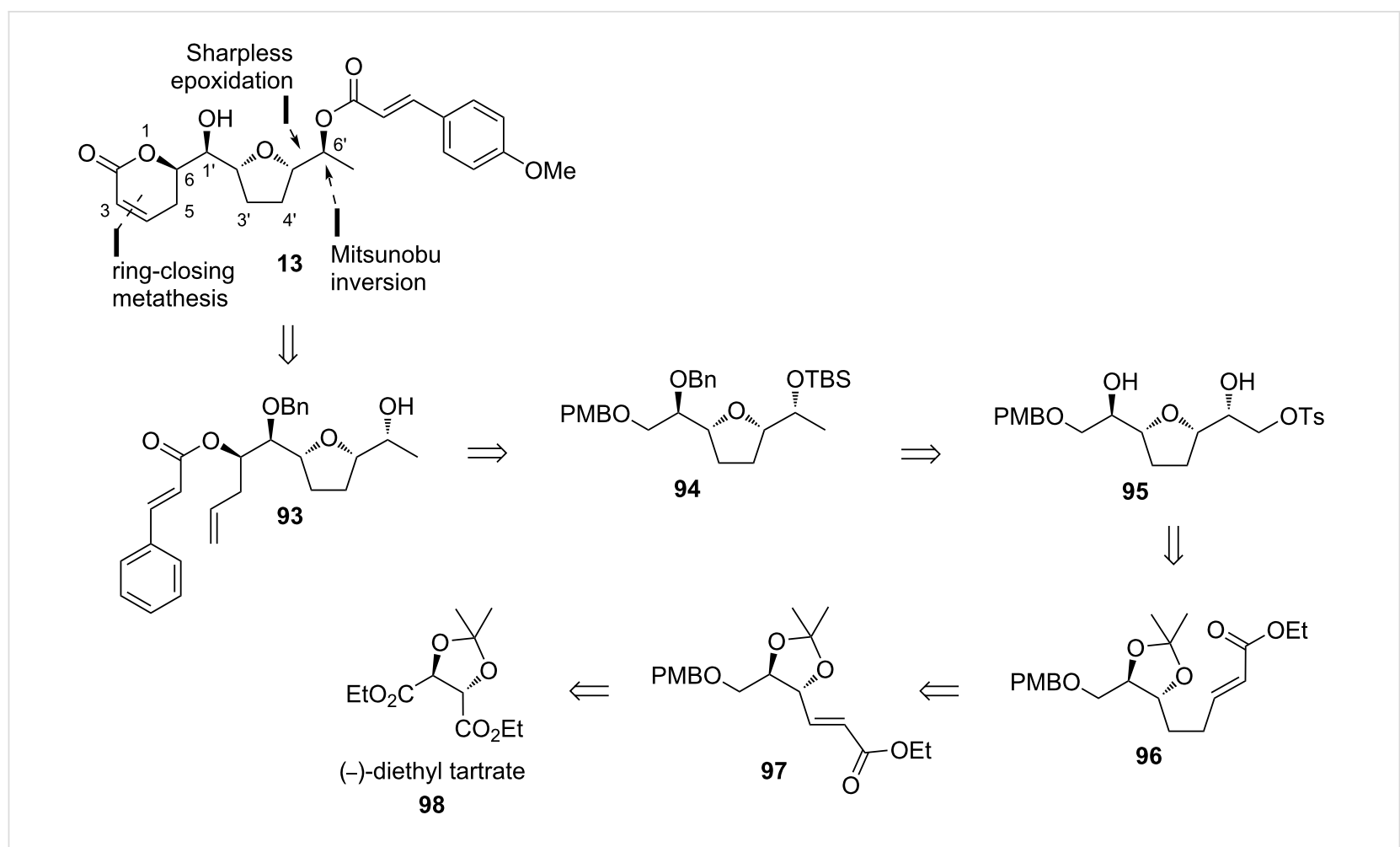

Scheme 11: Retrosynthetic analysis of brevipolide M (13) by Sabitha.

tion. The anticipated furan 95 was successfully isolated in $85 \%$ accompanied with the desired stereochemistry inversion at the C5' carbon. Treatment with excess $\mathrm{NaH}$ furnished a terminal epoxide derivative which after the sequential treatment with benzyl bromide and reduction with $\mathrm{LiAlH}_{4}$ afforded alcohol $\mathbf{1 0 2}(81 \%$ yield from $\mathbf{9 5})$. The free secondary alcohol was then protected as TBS ether $94(90 \%)$ and the PMB ether was cleaved to liberate the primary alcohol. After being oxidized with IBX, the aldehyde $\mathbf{1 0 3}$ was isolated in $68 \%$ yield over two steps. Application of the asymmetric Brown's allylation afforded $\mathbf{1 0 4}$ in $80 \%$ yield (dr 95:5) that was readily esterified to its cinnamate ester derivative in $80 \%$ yield. The TBS protecting group was removed under acidic conditions to give secondary alcohol 93 (85\%). Afterwards, the 5,6-dihydro- $\alpha$ pyrone functionality was constructed by applying a cross-metathesis protocol and the stereochemistry at C6' was inverted with $(E)$-p-methoxycinnamic acid (17) via a Mitsunobu esterification. The resulting product $\mathbf{1 0 6}$ contained all the correct stereochemistry, which after removal of the benzyl protection, provided the target molecule brevipolide $\mathrm{M}(\mathbf{1 3})$ as a colorless oil.

\section{Sabitha's strategy to brevipolide $M$ and $N(\mathbf{1 3}, \mathbf{1 4})$}

Following the previous success, Sabitha and Raju reported another approach to synthesize brevipolide M (13) which was shorter and more efficient than the former strategy [18]
Furthermore, this improved strategy was applied to achieve the first total synthesis of brevipolide N (14) by utilizing a different acid counterpart in the late esterification step. In the retrosynthesis, compound $\mathbf{1 0 7}$ is conceived as the branching intermediate to access both brevipolides $\mathrm{M}$ and $\mathrm{N}$ (Scheme 13). The 5,6-dihydro- $\alpha$-pyrone moiety can be derived from alkyne 108 via the sequential deprotection, Lindlar reduction, and oxidation. The propargylic alcohol moiety is introduced by the addition of a protected propargyl alcohol to the epoxide derived from triol 109. The furan ring is formed by an acidcatalyzed intramolecular cyclization of the alcohol intermediate obtained from the Noyori reduction of $\alpha, \beta$-unsaturated ketone 110. This compound is eventually constructed through Horner-Wardsworth-Emmons olefination of the known precursors 111 and 112, which are prepared from D-mannitol and L-lactic acid methyl ester, respectively.

The synthesis commenced with the reaction between aldehyde 111 and phosphonate ester 112 using $\mathrm{Ba}(\mathrm{OH})_{2} \cdot 8 \mathrm{H}_{2} \mathrm{O}$ to provide the unsaturated ketone $\mathbf{1 1 0}$ in $85 \%$ yield (Scheme 14). Application of a tandem 1,4/1,2-reduction to this compound under Noyori conditions gave the expected diastereomer $\mathbf{1 1 3}$ as the major product in 90\% yield (dr 96:4). After protection of the resulting free secondary alcohol as the tosyl ester 114 (88\%), this molecule was treated with an acid to remove the isopropylidene protection and induce intramolecular cyclization to the 2',5'- 


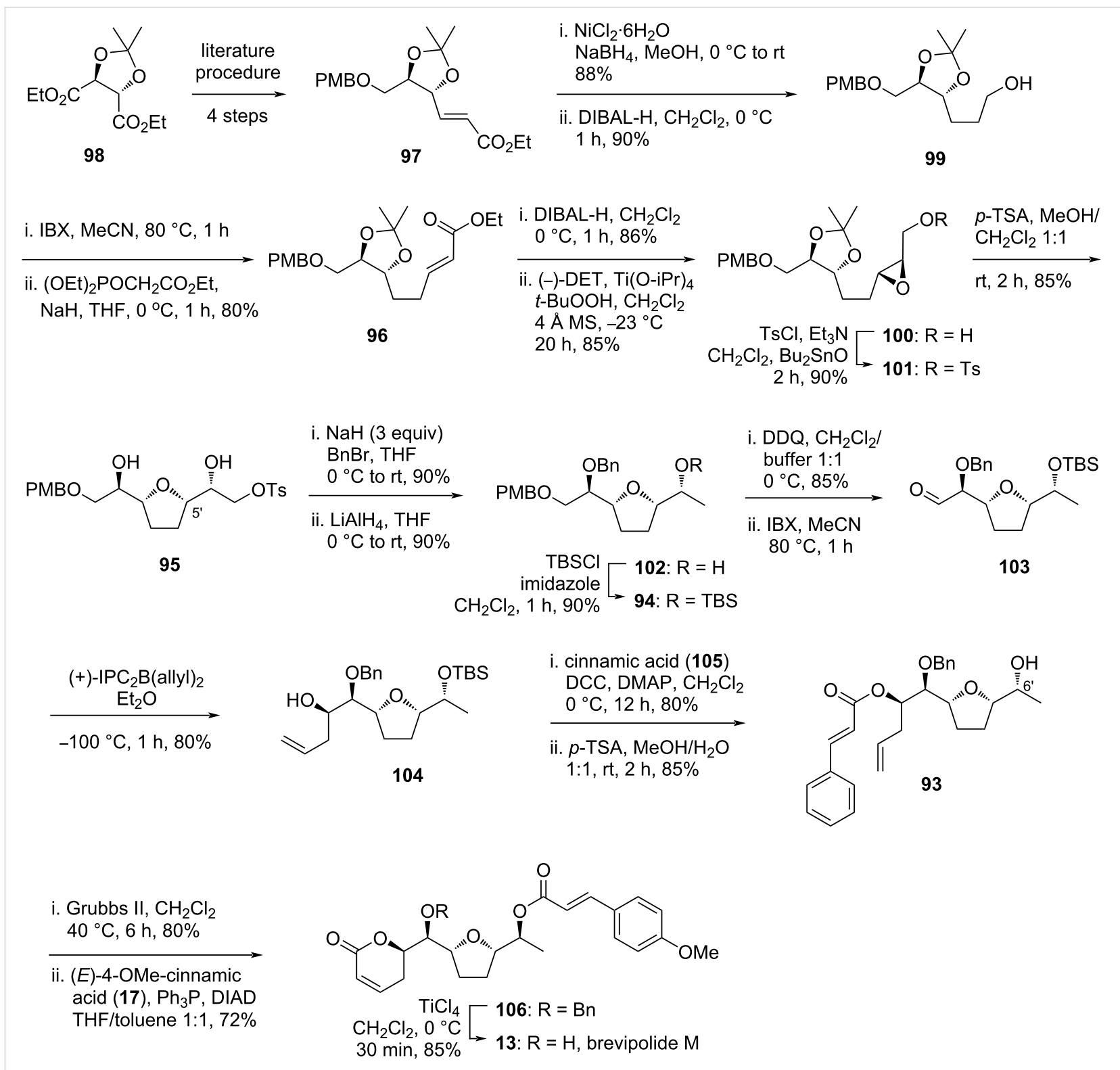

Scheme 12: Synthesis of brevipolide M (13) by Sabitha.

syn-furan 109 in $80 \%$ yield. This triol was subjected to excess sodium hydride and tosylating agent, and the mixture was allowed to react for 90 minutes, after which benzyl bromide was added to furnish the terminal epoxide $\mathbf{1 1 5}$ in $85 \%$ from 109. Then, the epoxide ring was opened with deprotonated propargylic ether 116. Global removal of the PMB functionality with DDQ gave triol 117. The partial reduction of the triple bond in $\mathbf{1 1 7}$ to the (Z)-olefin derivative was achieved using Lindlar catalyst and subsequent oxidation of the primary alcohol with the TEMPO/BAIB system facilitated the formation of pyrone 107. Initially, Sabitha and Raju intended to synthesize brevipolides $\mathrm{K}$ and $\mathrm{L}$ by esterification of this furanyl alcohol 107 with (Z)-4-OMe- and (Z)-4-OPMB-cinnamic acid
118 and 119, respectively. Unexpectedly, olefin isomerization occurred which led to the formation of brevipolides $\mathrm{M}(\mathbf{1 3})$ and $\mathrm{N}$ (15) after treatment with titanium tetrachloride in $\approx 85 \%$ yield each.

\section{Biological activities}

The extracts of Hyptis brevipes Poit. have been utilized by humanity across the world in tropical regions ranging from folk medicines [2,3,5-10] to pest management [2,3]. These traditional applications stimulated researchers to conduct biological studies with these plant extracts. A variety of bioactivities were then evidenced, such as antifungal, antibacterial [4,9] insecticidal [7], and radical scavenging [2]. Interestingly, the extracts 

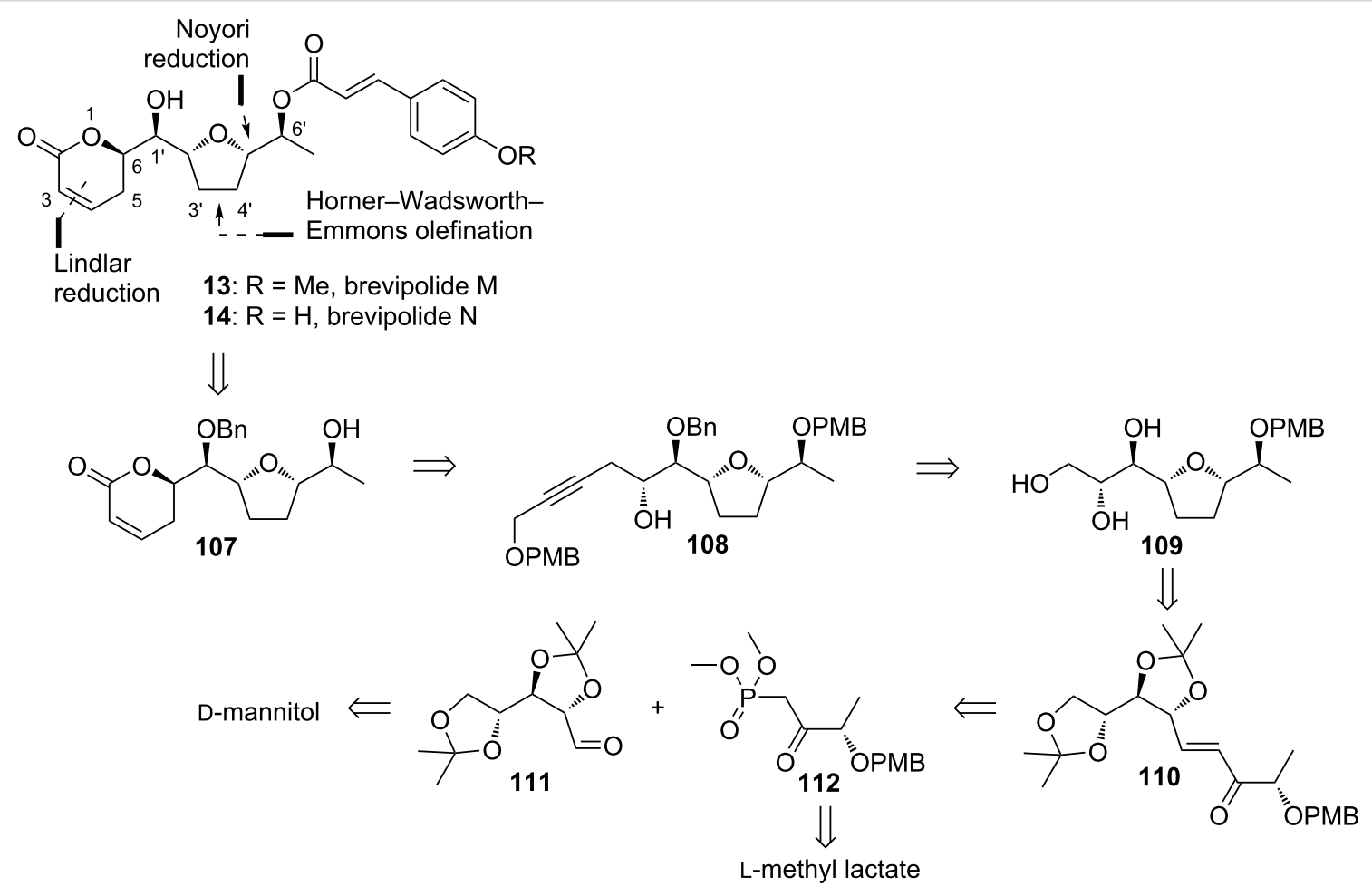

Scheme 13: Retrosynthetic analysis of brevipolides $M(13)$ and N (14) by Sabitha.
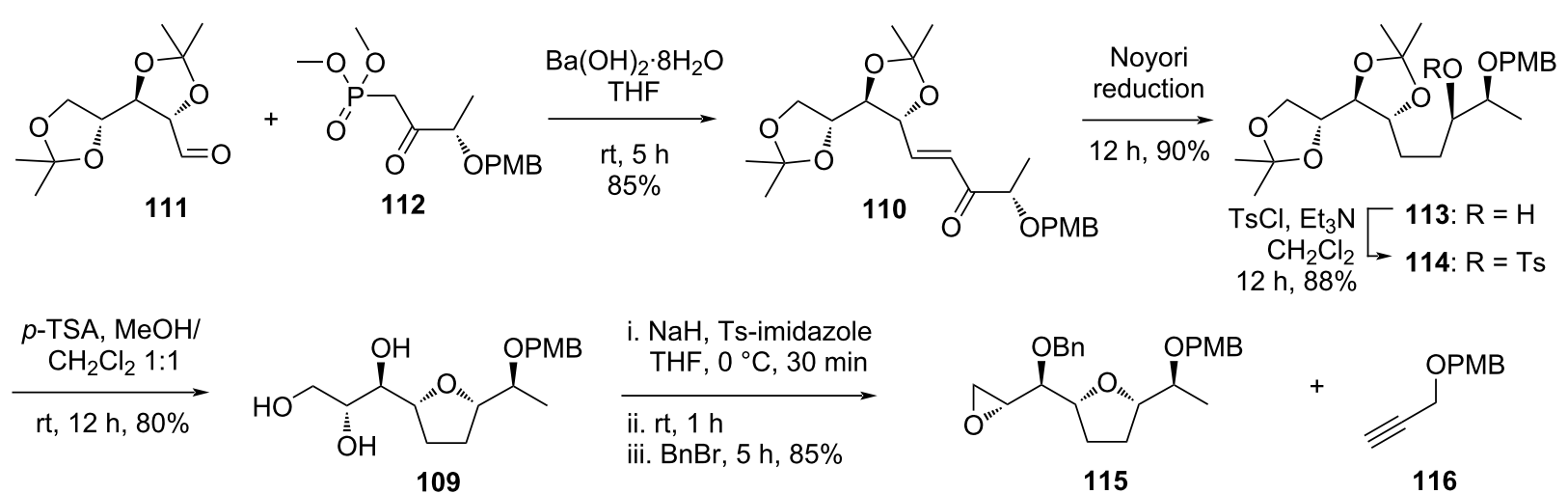
i. $n$-BuLi, $\mathrm{BF}_{3} \cdot \mathrm{Et}_{2} \mathrm{O}$
THF, $-788^{\circ} \mathrm{C}, 5 \mathrm{~h}, 90 \%$
$\stackrel{\text { ii. } \mathrm{DDQ}, \mathrm{CH}_{2} \mathrm{Cl}_{2} / \mathrm{H}_{2} \mathrm{O} 9: 1}{\longrightarrow}$
$0{ }^{\circ} \mathrm{C}, 2 \mathrm{~h}, 92 \%$

i. (Z)-4-OMe- (118) or (Z)-4OPMB-cinnamic acid (119)

DCC, DMAP, $\mathrm{CH}_{2} \mathrm{Cl}_{2}, 0^{\circ} \mathrm{C}$ $12 \mathrm{~h}, 82 \%$

ii. $\mathrm{TiCl}_{4}, \mathrm{CH}_{2} \mathrm{Cl}_{2}, 0^{\circ} \mathrm{C}, 30 \mathrm{~min}$

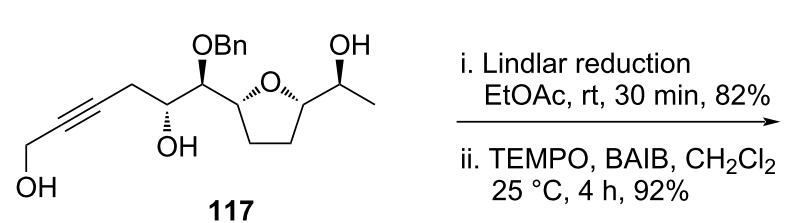<smiles>C[C@H](O)C1CCC([C@H](Cc2ccccc2)[C@H]2CC=CC(=O)O2)O1</smiles>

107 
also exhibited promising DNA intercalating agents [9] and antitumor activity [2]. The latter became more obvious when the chemical constituents of Hyptis brevipes Poit., the brevipolides A-F (1-6), were isolated for the first time by Kinghorn and co-workers in 2009 [4]. These compounds demonstrated cytotoxicity against various human cancer cells. Additionally, the research group led by Pereda-Miranda later isolated more members of brevipolide (1-15) from the same plant during 2013-2017 and further confirmed the cytotoxic activity of these natural products $[1,12]$.

The biological activity data of brevipolides A-O (1-15) and their analogs from literature has been summarized in Tables 1-3. Table 1 presents the cytotoxicity data of compounds $\mathbf{1}-\mathbf{1 5}$ and their analogs, if existing, against a range of cancer cell lines.

A cytotoxicity study against Lu1 human lung cancer cells was conducted for brevipolides A-G (1-7) by Kinghorn and co-workers but none of the compounds showed significant activity (Table 1, entries 1-7) [4]. These seven compounds were also evaluated against HT-29 human colon carcinoma cells and only three of them were potent (Table 1, entries 1, 2, and 6) with the lowest $\mathrm{ED}_{50}$ value of $5.8 \mu \mathrm{M}$ obtained for brevipolide
A (1) (Table 1, entry 1). Similar cytotoxicity evaluation was performed for brevipolides G-O (7-15) against HCT-15 human colon cancer cells (Table 1, entries 7-15), and relatively high $\mathrm{ED}_{50}$ values were obtained with the lowest number of $14.0 \mu \mathrm{M}$ observed for brevipolide I (9) (Table 1 entry 9) [1,12]. Moving forward, cytotoxicity examination against MCF-7 human breast carcinoma cells was done for all the brevipolide members (Table 1, entries 1-15) [1,4,12]. Brevipolides A-H (1-8) were evaluated in vivo (Table 1, entries 1-8), and the highest cytotoxicity against MCF-7 was obtained for brevipolide G (7) with $\mathrm{ED}_{50}$ values ranging between 3.6-5.1 $\mu \mathrm{M}$ (Table 1, entry 7). The remaining members of brevipolides were evaluated in vitro against MCF-7 cells (Table 1, entries 9-15), and the best result was obtained for brevipolide $\mathbf{J}(\mathbf{1 0})$ with an $\mathrm{IC}_{50}$ value of $8.4 \mu \mathrm{M}$ (Table 1, entry 10). Interestingly, brevipolide analogue 43, which is the reduced form of 6'-epi-brevipolide $\mathrm{H}$, showed even better in vitro cytotoxicity with an $\mathrm{IC}_{50}$ value of as low as $7.0 \mu \mathrm{M}$ (Table 1, entry 18) [14]. Also an evaluation on Hep-2 human laryngeal epidermoid cancer cells was conducted for brevipolides G-O (7-15) (Table 1, entries 7-15), and the lowest $\mathrm{IC}_{50}$ value $(8.8 \mu \mathrm{M})$ was observed for brevipolide $\mathrm{G}$ (7) (Table 1, entry 7) [1,12]. These nine compounds were also evaluated against HeLa, PC-3, and KB human cervix, prostate, and nasopharyngeal cancer cells, respectively, with the lowest $\mathrm{IC}_{50}$

\begin{tabular}{|c|c|c|c|c|c|c|c|c|c|c|}
\hline \multirow[t]{2}{*}{ entry } & \multirow[t]{2}{*}{ compounds } & \multicolumn{8}{|c|}{$\mathrm{ED}_{50}$ or $\mathrm{IC}_{50}(\mu \mathrm{M})$} & \multirow[t]{2}{*}{ reference } \\
\hline & & Lu1 & HT-29 & HCT-15 & MCF-7 & Hep-2 & HeLa & $\mathrm{PC}-3$ & $\mathrm{~KB}$ & \\
\hline 1 & 1 & NS & $5.8^{\mathrm{b}}$ & NT & $>10^{\mathrm{b}}$ & NT & NT & NT & NT & {$[4]$} \\
\hline 2 & 2 & NS & $6.1^{b}$ & NT & $6.1^{\mathrm{b}}$ & NT & NT & NT & NT & {$[4]$} \\
\hline 3 & 3 & NS & NS & NT & $>10^{\mathrm{b}}$ & NT & NT & NT & NT & {$[4]$} \\
\hline 4 & 4 & NS & NS & NT & $>10^{\mathrm{b}}$ & NT & NT & NT & NT & {$[4]$} \\
\hline 5 & 5 & NS & NS & NT & $>10^{\mathrm{b}}$ & NT & NT & NT & NT & {$[4]$} \\
\hline 6 & 6 & NS & $7.5^{\mathrm{b}}$ & NT & $6.7^{\mathrm{b}}$ & NT & NT & NT & NT & {$[4]$} \\
\hline 7 & 7 & NS & NS & $21.7^{c}$ & $3.6-5.1^{\mathrm{b}}$ & $8.8^{\mathrm{C}}$ & $0.18^{\mathrm{c}}$ & $13.2^{c}$ & $0.8^{\mathrm{C}}$ & {$[4,11,12]$} \\
\hline 8 & 8 & NT & NT & $17.0^{\mathrm{C}}$ & $5.2^{b}$ & $20.7^{c}$ & $14.5^{\mathrm{C}}$ & $13.5^{c}$ & $5.0^{\mathrm{C}}$ & {$[11,12]$} \\
\hline 9 & 9 & NT & NT & $14.0^{\mathrm{C}}$ & $17.7^{\mathrm{C}}$ & $15.7^{c}$ & $11.0^{\mathrm{C}}$ & $11.7^{c}$ & $4.7^{c}$ & {$[11,12]$} \\
\hline 10 & 10 & NT & NT & $25.7^{c}$ & $8.4^{\mathrm{C}}$ & $14.6^{\mathrm{C}}$ & $5.5^{\mathrm{C}}$ & $13.9^{c}$ & $2.9^{\mathrm{C}}$ & [12] \\
\hline 11 & 11 & NT & NT & $>24.8^{c}$ & $>24.8^{c}$ & $>24.8^{c}$ & $10.4^{c}$ & $24.8^{c}$ & $23.6^{c}$ & [1] \\
\hline 12 & 12 & NT & NT & $>25.7^{c}$ & $23.9^{c}$ & $19.8^{c}$ & $8.5^{\mathrm{C}}$ & $22.7^{c}$ & $19.3^{c}$ & {$[1]$} \\
\hline 13 & 13 & NT & NT & $>24.8^{c}$ & $>24.8^{c}$ & $14.2^{\mathrm{c}}$ & $14.9^{c}$ & $18.6^{c}$ & $4.2^{c}$ & [1] \\
\hline 14 & 14 & NT & NT & $>25.7^{c}$ & $>25.7^{c}$ & $>25.7^{c}$ & $24.4^{c}$ & $>25.7^{c}$ & $9.3^{c}$ & [1] \\
\hline 15 & 15 & $\mathrm{NT}$ & NT & $>24.7^{c}$ & $>24.7^{c}$ & $23.2^{c}$ & $17.1^{\mathrm{c}}$ & $>24.7^{c}$ & $12.1^{c}$ & {$[1]$} \\
\hline 16 & ent-8 & $\mathrm{NT}$ & NT & NT & NT & NT & NT & $19.2^{\mathrm{c}}$ & NT & [16] \\
\hline 17 & 41 & $\mathrm{NT}$ & NT & NT & $22.4^{c}$ & NT & NT & NT & NT & [14] \\
\hline 18 & 43 & NT & NT & NT & $7.0^{\mathrm{C}}$ & NT & NT & NT & NT & [14] \\
\hline
\end{tabular}

aAbbreviations: Lu1 = lung carcinoma; HT-29 = colon carcinoma; HCT-15 = colon carcinoma; MCF-7 = breast carcinoma; Hep-2 = laryngeal epidermoid carcinoma; HeLa = cervix carcinoma; $\mathrm{PC}-3$ = prostate carcinoma; $\mathrm{KB}=$ nasopharyngeal carcinoma; $\mathrm{NS}=$ not significant; $\mathrm{NT}=$ not tested. ${ }^{\mathrm{b}} \mathrm{ED} \mathrm{D}_{50}$. $\mathrm{CIC}_{50}$. 
values successively obtained for brevipolides $G(7), I(9)$ and $G$ (7) $(0.18,11.7$, and $0.8 \mu \mathrm{M}$, respectively) (Table 1 , entries 7,9 , and 7) $[1,12]$. The non-natural brevipolide $\mathrm{H}$ (ent-8) was also evaluated against PC-3 human prostate carcinoma cells but gave no better cytotoxicity results as compared to the natural version (Table 1 , entry 16 vs entry 8 ) $[16,19]$.

Table 2 summarizes the results of other important biological evaluations for brevipolides A-I (1-9). The mitochondrial transmembrane potential assay was investigated for brevipolides A-G (1-7) (Table 2, entries 1-7). A very low $\mathrm{ED}_{50}$ value of $8.5 \mathrm{nM}$ was obtained for brevipolide C (3) (Table 2, entry 3) [4], making it a very potent lead compound for anticancer candidates related to mitochondrial dysfunction effect. A reduction in the mitochondrial membrane potential
(MMP) could also indicate apoptosis [20]. These seven compounds, 1-7, were also evaluated for enzyme-based ELISA NF- $\mathrm{KB}$ and proteasome inhibition assays (Table 2, entries 1-7), but only brevipolide $\mathrm{G}(7)$ and brevipolide $\mathrm{C}(3)$ showed significant activities with $\mathrm{ED}_{50}$ values of 15.3 and $38.0 \mu \mathrm{M}$, respectively (Table 2, entries 7 and 3) [4]. Lastly, brevipolides G-I (7-9) were found to inhibit the CCR5 receptor signaling as measured by a calcium mobilization assay with $\mathrm{IC}_{50}$ values of $15.5,13.7$, and $18.0 \mu \mathrm{M}$, respectively, which make them potential agents for treating HIV disease (Table 2, entries 7-9) [11].

Giménez and co-workers, in 2019, reported the antiparasitic study of brevipolides $\mathrm{C}, \mathrm{G}, \mathrm{H}$, and $\mathrm{J}(\mathbf{3}, \mathbf{7}, \mathbf{8}$, and 10) and the $\mathrm{IC}_{50}(\mathrm{mM})$ data obtained are summarized in Table 3 [5]. These compounds demonstrated varying activity levels against

Table 2: Summary of other biological evaluations for brevipolides A-I (1-9) found in the literature. ${ }^{a}$

\begin{tabular}{|c|c|c|c|c|c|c|}
\hline \multirow[t]{2}{*}{ entry } & \multirow[t]{2}{*}{ compound } & \multicolumn{4}{|c|}{$\mathrm{ED}_{50}$ or $\mathrm{IC}_{50}(\mu \mathrm{M})$} & \multirow[t]{2}{*}{ reference } \\
\hline & & $\begin{array}{l}\text { mitochondrial } \\
\text { transmembrane } \\
\text { potential assay }\end{array}$ & $\begin{array}{l}\text { enzyme-based } \\
\text { ELISA NF-kB } \\
\text { assay }\end{array}$ & $\begin{array}{l}\text { proteasome } \\
\text { inhibition assay }\end{array}$ & $\begin{array}{l}\text { chemokine } \\
\text { CCR5 receptor }\end{array}$ & \\
\hline 1 & 1 & NS & $>50^{\mathrm{b}}$ & NS & NT & {$[4]$} \\
\hline 2 & 2 & NS & $>50^{\mathrm{b}}$ & NS & NT & {$[4]$} \\
\hline 3 & 3 & $0.0085^{\mathrm{b}}$ & $>50^{\mathrm{b}}$ & $38.0^{\mathrm{b}}$ & NT & {$[4]$} \\
\hline 4 & 4 & NS & $>50^{\mathrm{b}}$ & $44.5^{\mathrm{b}}$ & NT & {$[4]$} \\
\hline 5 & 5 & NS & $>50^{\mathrm{b}}$ & NS & NT & {$[4]$} \\
\hline 6 & 6 & NS & $>50^{\mathrm{b}}$ & NS & NT & {$[4]$} \\
\hline 7 & 7 & $0.075^{b}$ & $15.3^{\mathrm{b}}$ & NS & $15.5^{c}$ & {$[4,11]$} \\
\hline 8 & 8 & NT & NT & NT & $13.7^{c}$ & [11] \\
\hline 9 & 9 & NT & NT & NT & $18.0^{c}$ & [11] \\
\hline
\end{tabular}

aAbbreviations: NS = not significant; NT = not tested. ${ }^{\mathrm{b}} \mathrm{ED}_{50} \cdot{ }^{\mathrm{c}} \mathrm{C}_{50}$

Table 3: $\mathrm{IC}_{50}(\mathrm{mM})$ values of $\mathbf{3}, \mathbf{7}, \mathbf{8}$, and $\mathbf{1 0}$ (brevipolides $\mathrm{C}, \mathrm{G}, \mathrm{H}$, and J) against protozoa parasites and HeLa cells. ${ }^{\mathrm{a}}$

\begin{tabular}{|c|c|c|c|c|c|}
\hline \multirow[t]{2}{*}{ entry } & \multirow[t]{2}{*}{ protozoa parasites and cancer cells } & \multicolumn{4}{|c|}{ compounds } \\
\hline & & 3 & 7 & 8 & 10 \\
\hline 1 & Lma & $202.0 \pm 8.0$ & $62.1 \pm 23.3$ & $18.7 \pm 6.7$ & $24.0 \pm 7.2$ \\
\hline 2 & Lae & $>248.5$ & $121.6 \pm 16.6$ & $17.5 \pm 3.5$ & $41.5 \pm 1.0$ \\
\hline 3 & M2904 & $182.4 \pm 67.1$ & $155.5 \pm 32.1$ & $12.5 \pm 1.5$ & $120.3 \pm 36.3$ \\
\hline 4 & LbG & $167.2 \pm 59.1$ & $>258.8$ & $32.5 \pm 15.0$ & $146.5 \pm 35.1$ \\
\hline 5 & Llan & $>248.5$ & $155.5 \pm 18.1$ & $23.5 \pm 1.0$ & $64.8 \pm 26.4$ \\
\hline 6 & T.C & $>248.5$ & $>258.8$ & $50.4 \pm 8.7$ & $149.8 \pm 17.3$ \\
\hline 7 & P.f & $54.4 \pm 18.6$ & $56.9 \pm 9.8$ & $34.0 \pm 16.0$ & $34.6 \pm 13.2$ \\
\hline 8 & G.I & $>248.5$ & $111.3 \pm 36.2$ & $76.7 \pm 10.0$ & $43.2 \pm 0.7$ \\
\hline 9 & HeLa & $47.2 \pm 7.7$ & $82.8 \pm 4.7$ & $94.9 \pm 4.0$ & $70.8 \pm 9.4$ \\
\hline
\end{tabular}

aAbbreviations: Lma: Leishmania amazonensis; Lae: L. aethiopica; M2904: L. braziliensis; LbG: L. braziliensis native; Llan: L. lainsoni, native; T.c: Trypanosoma cruzi; P.f: Plasmodium falciparum; G.I: Giardia lamblia; HeLa: human cervix carcinoma. 
multiple Leishmania strains, Trypanosoma cruzy, Plasmodium falciparum, and Giardia lamblia (Table 3, entries 1-8). Except for $G$. lamblia, brevipolide H (8) showed the best antiparasitic activity against all the tested human intestine parasites with $\mathrm{IC}_{50}$ values of $12.5-50.4 \mathrm{mM}$. Thus, this compound has great potential as a lead structure in parasite research. A cytotoxicity study of these four compounds against HeLa human cervix cancer cells was also performed, and the results showed values spanning between 47.2-70.8 mM (Table 3, entry 9). However, these results were considerably much lower than those obtained by the Kinghorn [4] and Pereda-Miranda [12] research groups, which lied in a micromolar order (see Table 1, entries 3, 7, 8, and 10). This prominent difference might arise from the differing methods used.

In the same year, Borges and co-workers performed an ovicidal activity evaluation against Haemonchus placei eggs using the extract of the Hyptis brevipes plant [21]. In tropical areas, $H$. place i is particularly harmful to cattle, causing hypoproteinemia, anemia, and anorexia in the host animals [22]. The extract showed hatchability inhibition with $\mathrm{ED}_{50}$ and $\mathrm{EC}_{50}$ values of 3.34 and $5.71 \mathrm{mg} / \mathrm{mL}$, respectively. A complete inhibition was achieved at the concentration of $25 \mathrm{mg} / \mathrm{mL}$ of the H. brevipes extract. Analysis of data combination from ovicidal activity, mass spectrometry, and metabolomics using HPLC- diode array detector-MS (HPLC-DAD-MS), partial least squares regression analysis (PLS-DA), and a correlation map (univariate correlation analyses) enabled the prediction of compounds that have a positive correlation with biological activity. This analysis attributed two detected $[\mathrm{M}-\mathrm{H}]^{-}$signals to dihydrobrevipolides $\mathrm{C}$ and F. Nevertheless, further structural identification was not performed.

\section{Conclusion}

The characteristic structural features of 5,6-dihydro- $\alpha$-pyrone derivatives isolated from Hyptis brevipes Poit., i.e., the brevipolides $\mathrm{A}-\mathrm{O}$, parallel with their appealing biological activity, in addition to the fact that they were produced in a small quantity from nature, make these natural products highly relevant when considering total synthesis. Since the first attempt to prepare brevipolide $\mathrm{H}$ by Kumaraswamy in 2014, several model, formal, and total syntheses of brevipolides have been performed, adding more understanding to the chemical and biological aspects of these compounds. In particular, in this review, the main strategies for the synthesis of brevipolides involve: 1) olefin metathesis; 2) asymmetric dihydroxylation and epoxidation; 3 ) asymmetric hydrogenation; 4) Horner-Wadsworth-Emmons olefination; and 5) cyclopropanation, which are summarized in Table 4, including the overall yields and the number of steps required.

Table 4: Summary of the syntheses described in this review.

\begin{tabular}{|c|c|c|c|c|}
\hline synthesis & products & key transformations & overall yield & number of steps \\
\hline $\begin{array}{l}\text { Kumaraswamy [14], } \\
2014\end{array}$ & $\begin{array}{l}\text { reduced 6'-epi-brevipolide } \\
\mathrm{H}(\mathbf{4 3})\end{array}$ & $\begin{array}{l}\text { C4-C5: ring-closing metathesis } \\
\text { C5-C6: vinyl Grignard addition } \\
\text { C1'-OH: VO-catalyzed epoxidation } \\
\text { C6'-OH: catalytic asymmetric transfer } \\
\text { hydrogenation } \\
\text { cyclopropane ring: Furukawa's modified } \\
\text { Simmons-Smith }\end{array}$ & $2.5 \%$ from 20 & 23 \\
\hline Hou [16], 2014 & ent-brevipolide $\mathrm{H}$ (ent-8) & $\begin{array}{l}\text { C4-C5: ring-closing metathesis } \\
\text { C2'-C4': cross metathesis } \\
\text { C6'-OH: Sharpless asymmetric } \\
\text { dihydroxylation } \\
\text { cyclopropane ring: Michael-initiated ring } \\
\text { closure }\end{array}$ & $10 \%$ from ent-49 & 11 \\
\hline Mohapatra [13], 2015 & $\begin{array}{l}\text { C1-C12 fragment of } \\
\text { reduced 6'-epi-brevipolide } \\
\mathrm{H}(77)\end{array}$ & $\begin{array}{l}\mathrm{C} 3=\mathrm{C} 4 \text { : ring-closing metathesis } \\
\text { C5-C6: Brown asymmetric allylation } \\
\text { C1'-OH: anti-selective reduction } \\
\text { C6'-OH: Jørgensen epoxidation } \\
\text { cyclopropane ring: Furukawa's modified } \\
\text { Simmons-Smith }\end{array}$ & $12.5 \%$ from 62 & 18 \\
\hline Hou [15], 2016 & brevipolide H (8) & $\begin{array}{l}\text { C3=C4: ring-closing metathesis } \\
\text { C5-C6: vinyl Grignard addition } \\
\text { C6-OH: Sharpless epoxidation } \\
\text { C2'-C4': cross metathesis } \\
\text { C6'-OH: Sharpless epoxidation } \\
\text { cyclopropane ring: Furukawa's modified } \\
\text { Simmons-Smith }\end{array}$ & $3.5 \%$ from 85 & 15 \\
\hline
\end{tabular}


Table 4: Summary of the syntheses described in this review. (continued)

Sabitha [17], 2017 brevipolide M (13)

Sabitha [18], 2018

brevipolide $\mathrm{M}(\mathbf{1 3})$ and $\mathrm{N}$

(14)

\author{
$\mathrm{C} 3=\mathrm{C} 4$ : ring-closing metathesis \\ C5-C6: Brown asymmetric allylation \\ C3'-C4': Horner-Wadsworth-Emmons \\ olefination \\ C5'-C6': Horner-Wadsworth-Emmons \\ olefination \\ C5'-OH: Sharpless epoxidation \\ C6'-OH: Sharpless epoxidation, \\ Mitsunobu inversion \\ furan ring: acid-catalyzed cyclization \\ C3=C4: Lindlar reduction \\ C5-C6: alkyne addition \\ C3'-C4': Horner-Wadsworth-Emmons \\ olefination \\ C5'-OH: Noyori reduction \\ furan ring: acid-catalyzed cyclization
}

$5.8 \%$ from $97 \quad 17$

$20.2 \%$ from $111 \quad 11$
This work is expected to provide useful information for researchers to design new synthetic methodologies for reproducing these natural products and their analogues as well as to develop new pharmaceuticals from them.

\section{Acknowledgements}

The authors thank Assoc. Prof. Kellie L. Tuck, from the School of Chemistry at Monash University, for her time and effort to improve the scientific English of this review.

\section{ORCID ${ }^{\circledR}$ iDs}

Yudhi D. Kurniawan - https://orcid.org/0000-0002-8432-3629

A'liyatur Rosyidah - https://orcid.org/0000-0001-8427-4364

\section{References}

1. Suárez-Ortiz, G. A.; Cerda-García-Rojas, C. M.; Fragoso-Serrano, M.; Pereda-Miranda, R. J. Nat. Prod. 2017, 80, 181-189. doi:10.1021/acs.jnatprod.6b00953

2. Xu, D.-H.; Huang, Y.-S.; Jiang, D.-Q.; Yuan, K. Pharm. Biol. (Abingdon, U. K.) 2013, 51, 1125-1130. doi:10.3109/13880209.2013.781195

3. Bhuiyan, M. N. I.; Begum, J.; Nandi, N. C. J. Med. Plants Res. 2010, 4, 2128-2131.

4. Deng, Y.; Balunas, M. J.; Kim, J.-A.; Lantvit, D. D.; Chin, Y.-W.; Chai, H.; Sugiarso, S.; Kardono, L. B. S.; Fong, H. H. S.; Pezzuto, J. M.; Swanson, S. M.; Carcache de Blanco, E. J.; Kinghorn, A. D. J. Nat. Prod. 2009, 72, 1165-1169. doi:10.1021/np9001724

5. Limachi, I.; Condo, C.; Palma, C.; Nina, N.; Salamanca, E.; Ticona, J. C.; Udaeta, E.; Flores, N.; Serato, A.; Marupa, N.; Chao, B.; Ibaguari, G.; Nay, C.; Manner, S.; Sterner, O.; Giménez, A. Nat. Prod. Commun. 2019, 14, 55-58. doi:10.1177/1934578×1901400115

6. Falah, F.; Hadiwibowo, N. Indones. J. For. Res. 2017, 4, 49-68. doi:10.20886/ijf.2017.4.1.49-68

7. Sakr, H. H.; Roshdy, S. H.; El-Seedi, H. R. J. Appl. Pharm. Sci. 2013, 3, 83-88.
8. Roosita, K.; Kusharto, C. M.; Sekiyama, M.; Fachrurozi, Y.; Ohtsuka, R. J. Ethnopharmacol. 2008, 115, 72-81. doi:10.1016/j.jep.2007.09.010

9. Gupta, M. P.; Monge, A.; Karikas, G. A.; Lopez de Cerain, A.; Solis, P. N.; de Leon, E.; Trujillo, M.; Suarez, O.; Wilson, F.; Montenegro, G.; Noriega, Y.; Santana, A. I.; Correa, M.; Sanchez, C. Int. J. Pharmacogn. (Lisse, Neth.) 1996, 34, 19-27. doi:10.1076/phbi.34.1.19.13180

10. Goun, E.; Cunningham, G.; Chu, D.; Nguyen, C.; Miles, D. Fitoterapia 2003, 74, 592-596. doi:10.1016/s0367-326x(03)00117-5

11. Hegde, V. R.; Pu, H.; Patel, M.; Das, P. R.; Strizki, J.; Gullo, V. P.; Chou, C.-C.; Buevich, A. V.; Chan, T.-M. Bioorg. Med. Chem. Lett. 2004, 14, 5339-5342. doi:10.1016/j.bmcl.2004.08.021

12. Suárez-Ortiz, G. A.; Cerda-García-Rojas, C. M.; Hernández-Rojas, A.; Pereda-Miranda, R. J. Nat. Prod. 2013, 76, 72-78. doi:10.1021/np300740h

13. Mohapatra, D. K.; Kanikarapu, S.; Naidu, P. R.; Yadav, J. S. Tetrahedron Lett. 2015, 56, 1041-1044. doi:10.1016/j.tetlet.2014.12.125

14. Kumaraswamy, G.; Jayaprakash, N.; Rambabu, D.; Ganguly, A.; Banerjee, R. Org. Biomol. Chem. 2014, 12, 1793-1803. doi:10.1039/c3ob42367k

15. Chen, C.-N.; Hou, D.-R. Org. Biomol. Chem. 2016, 14, 6762-6768. doi:10.1039/c6ob01071g

16. Lin, J.-W.; Kurniawan, Y. D.; Chang, W.-J.; Leu, W.-J.; Chan, S.-H.; Hou, D.-R. Org. Lett. 2014, 16, 5328-5331. doi:10.1021/ol502507k

17. Shiva Raju, K.; Sabitha, G. Org. Biomol. Chem. 2017, 15, 6393-6400. doi:10.1039/c7ob01438d

18. Raju, K. S.; Sabitha, G. Tetrahedron Lett. 2018, 59, 4213-4215. doi:10.1016/j.tetlet.2018.10.018

19. Sheng, Y.-H.; Leu, W.-J.; Chen, C.-N.; Hsu, J.-L.; Liu, Y.-T.; Hsu, L.-C.; Hou, D.-R.; Guh, J.-H. Molecules 2020, 25, 2929. doi:10.3390/molecules25122929

20. Sakamuru, S.; Attene-Ramos, M. S.; Xia, M. Mitochondrial Membrane Potential Assay. In High-Throughput Screening Assays in Toxicology; Zhu, H.; Xia, M., Eds.; Springer: New York, NY, USA, 2016; p 18.

21. Borges, D. G. L.; Echeverria, J. T.; de Oliveira, T. L.; Heckler, R. P.; de Freitas, M. G.; Damasceno-Junior, G. A.; Carollo, C. A.; Borges, F. d. A. PLoS One 2019, 14, e0211237. doi:10.1371/journal.pone.0211237 
22. Gennari, S. M.; Vieira Bressan, M. C. R.; Rogero, J. R.;

MacLean, J. M.; Duncan, J. L. Vet. Parasitol. 1991, 38, 163-172.

doi:10.1016/0304-4017(91)90126-g

\section{License and Terms}

This is an Open Access article under the terms of the Creative Commons Attribution License

(https://creativecommons.org/licenses/by/4.0). Please note that the reuse, redistribution and reproduction in particular requires that the author(s) and source are credited and that individual graphics may be subject to special legal provisions.

The license is subject to the Beilstein Journal of Organic Chemistry terms and conditions:

(https://www.beilstein-journals.org/bjoc/terms)

The definitive version of this article is the electronic one which can be found at:

https://doi.org/10.3762/bjoc.17.157 